\title{
4 Obedient artists and mediators
}

\author{
Women icon painters in the \\ Finnish Orthodox Church \\ from the mid-twentieth to the \\ twenty-first century
}

\section{Katariina Husso}

In the discipline of art history, the question of gender has occupied academic researchers for decades. Generally, gender is understood as a system of power. The art historian Griselda Pollock (2014), for instance, maintains that "as an axis of power relations, gender can be shown to shape social existence of men and women and determine artistic representations." In addition to art history, visual culture studies have broadened their scope from objects and artists to various discourses and wider contexts such as the social circumstances of art and its production. The story of art and its institutions, like its historiography, have been shown to represent the Western, white male narrative, excluding women artists. This is equally true of the history of icon art of Eastern Christianity.

My aim in this chapter is to examine the role of women icon painters in the Finnish Orthodox Church from the 1950s to today. I use the concept of gender as an analytic category to reveal different attitudes, concepts, and phenomena related to Orthodox icon production in the recent past and present.

\section{The modernist return to tradition}

Modernism as a period in art history (referring especially to painting) is commonly defined as dating from roughly the 1860 s to the 1970 s. The term is used to describe the style and ideology of the art produced during that era. Specifically, it can be understood to refer to the philosophy of modern art. The most common examples of modernist art are based on the rejection of tradition; at the same time, a contrary approach dwelled on ancient art and sought a return to tradition. To make this diversity visible, the contemporary composer Ivan Moody $(2014,27)$ has suggested that it would be more helpful to speak in terms of modernisms rather than a single, linear modernism. It is reasonable to assume that no European and North American art, icon production 


\section{Katariina Husso}

included, has remained outside history and time, resisting modernist influences (see Drucker 1998, 248; Lepine, Lodder, and McKever 2015, passim).

The "rediscovery" of the icon (Otkrytie ikony) was a modernist phenomenon in prerevolutionary Russia, which paved the way for revivalist icon painting. The revival of the medieval icon tradition in the late nineteenth and early twentieth centuries was closely connected both to the development of new restoration methods and to religious, philosophical, and aesthetic discussions. This profound rethinking of religious art focused on the very concept of the icon itself. In the revivalist discourse, icon no longer referred to just any Orthodox devotional image, but specifically to images painted according to the traditional mode of representation following ancient prototypes and applying the egg tempera technique (Belting 1996, 19-21; Kotkavaara 1999, 155). The twentieth-century revivalist approach introduced a new stylistic and artistic ideal for Orthodox iconography, which was strongly influenced by modern theories of art. The Orthodox writers Evgeny Trubetskoy, Pavel Florensky, and Léonid Ouspensky were pivotal figures in the modern Orthodox "rediscovery" of the icon and in formulating a modern doctrine of icon theology. ${ }^{1}$ Revivalist views rapidly spread to Western Europe via Russian émigrés and the writings of Trubetskoy, Florensky, and especially Ouspensky (Kotkavaara 1999, passim; Freeman 2018, 137-151).

The art historian Kari Kotkavaara has pointed out how the revivalist approach broadened traditional professional skill, with an emphasis on artistic activity. The crucial difference between a traditional icon painter and a modern revivalist icon painter lay in the individual's freedom of choice and liberty to make conscious decisions. Traditional icon painters produced icons for the devotional images market in different styles according to their patrons' wishes. They usually painted in workshops where several craft workers and apprentices were all responsible for different stages of the work such as preparing the panel, gilding, or painting the ground layers. The master supervised and directed production and put the finishing touches to the images. In contrast, revivalist icon painters were motivated by an artistic, and usually also a religious, desire to paint and create icons. Also, the process of manufacturing icons was different. The holy image was a unique work of art and the artist completed it from the panel's grounding to the final coating of olifa (linseed oil varnish). The magnitude of this change is reflected in the fact that no revivalist icon painters learned their skills in a workshop (Kotkavaara 1999, 12).

The classical literature of art history makes no mention of women as icon painters; the few painters we know by name are men. Therefore, it is quite commonly argued that there were no women iconographers in Russia before the twentieth century (see Yazykova 2010, 72). This conception, however, reflects the old art-history paradigm, in which women artists were invisible. According to Nina M. Turtsova (2010, 10-15), women have, in fact, been painting icons in Russia for over 400 years. At first, they were 
active in workshops, as members of icon painting families. Later, when the large-scale production of icons began in the early nineteenth century, the studios where women could learn icon painting and where more experienced female painters worked were often situated in convents. ${ }^{2}$ Moreover, during this period, interest in icon painting also grew in wealthy merchant families and among the aristocracy, women as well as men.

There were several women painters among the revivalists, mostly aristocrats. Many of them-for instance, Princess Natalia G. Jashvil, Tatyana V. Kosinskaya, Elena S. L'vova, Julia N. Reitlinger (Sister Joanna), Maria N. Sokolova (Mother Juliania), Sofia Volkova-Irmanova, and (Mother) Maria Skobtsova-emigrated to Western Europe after the Revolution (Kotkavaara 1999, 198-199, 210-224, 258-263, 288-290; Yazykova 2010, 72, 77). Overall, it is safe to say that the appearance of Russian women iconographers as independent artists was connected to the modernist phase of icon art.

\section{Women artists as iconographers in post-Second World War Finland}

The easternmost province of Finland before the Second World War, known as Karelia, had been in contact with Russian Orthodoxy for centuries. The Monastery of Valaam (Valamo in Finnish), situated on an island in Lake Ladoga, was a religious center and a place for the artistic production of ecclesiastical artifacts. At the turn of the twentieth century, the art atelier of the monastery was especially famous for its icon production. However, as a result of the Second World War, the majority of Orthodox Finns had to leave their homes in Karelia. The monks, too, became homeless evacuees, and their art atelier closed. The war years thus broke the continuum of icon painting in Finland.

Orthodox Finns were introduced to revivalist icon painting and the teachings of what is known as icon theology in the aftermath of the Second World War, when large-scale rebuilding started all over Finland. In the Finnish Orthodox Church, this phase is known as the reconstruction period. The ten-year project focused chiefly on building new churches and chapels, for approximately 90 percent of the buildings and land owned by the Finnish Orthodox Church was situated on territory that had been ceded to the Soviet Union. The project also covered interior design, including furnishing the new houses of worship with icons.

One of the many Finnish artists hired to paint holy images was Martha Neiglick-Platonoff (1889-1964), who painted nearly a hundred icons for new churches and chapels. Neiglick-Platonoff had worked for decades at the Finnish National Opera and the Swedish Theater in Helsinki as a costume and set designer. She was also a distinguished portrait painter. She had studied art in Finland and abroad in the 1910s, but only began to paint icons after she converted to Orthodoxy at the age of 59. She studied Orthodox iconography independently from Christian artworks in European 


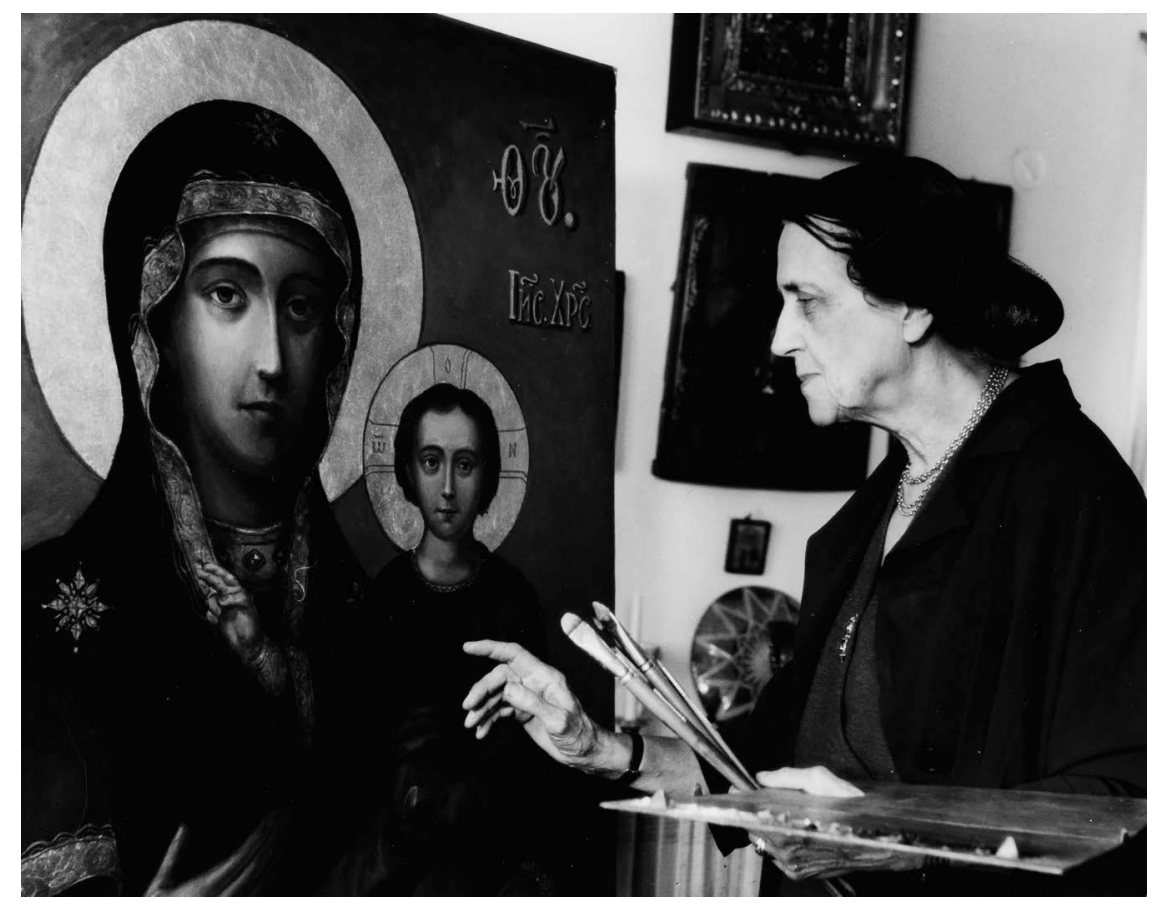

Figure 4.1 The artist Martha Neiglick-Platonoff conserving an old icon of the Mother of God in the 1950s. Jalmari Aarnio / RIISA - The Orthodox Church Museum of Finland (OKM VA 2547:1).

museums and churches (Husso 2011, 101-102). Her personal history was full of loss. Her father passed away the very year she was born. In 1921, she lost her husband, the Russian naval officer Lieutenant Igor Platonoff. Finally, during the Second World War, she had to face the death of her only child, Lieutenant Stephen Platonoff, in battle on the Karelian Isthmus (Ihanus 2006; Hätönen 2017, 1).

Another well-known Finnish artist who also took an interest in icon painting was Ina Colliander (1905-1985), a colleague of Neiglick-Platonoff. She had immigrated to Finland in her youth in 1923 and had married another émigré from St. Petersburg, the writer Tito (Fritiof) Colliander, in 1930. Six years later, while living in the small Estonian town of Pechory, near the Pskovo-Petchersky Monastery, they both converted to Orthodoxy. Colliander is famous for her graphic art, especially woodcuts, which are often inspired by Orthodox iconography. She also created religious mosaics for some Orthodox churches in Finland from the 1960s onwards (Anttonen 2000; Konttinen 2017, 203-204). 


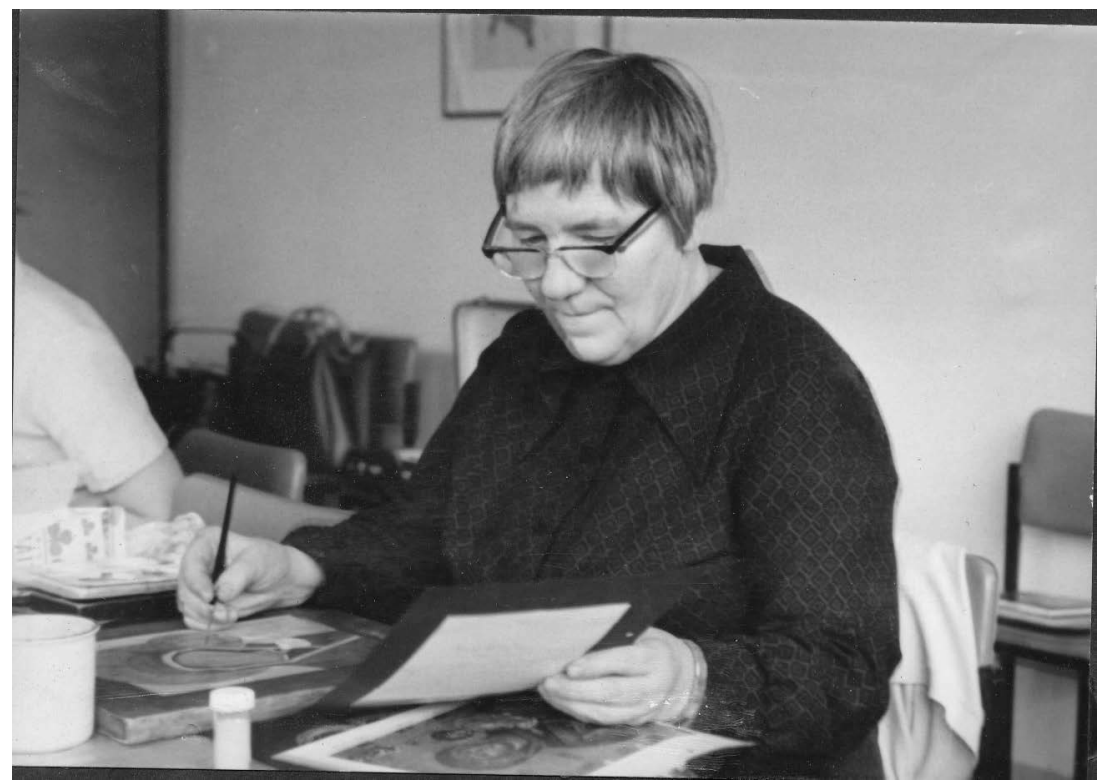

Figure 4.2 The language of ancient iconography was studied through art history. The artist Ina Colliander painting an icon of the Mother of God of Kazan in 1968. Helena Nikkanen / Private collection.

For both Colliander and Neiglick-Platonoff, the will to paint icons arose primarily from religious conviction. Both had been educated and started their careers as artists, but perceived Orthodox iconography as a special form of artistic expression, which required personal devotion and humility. This became evident when both artists were asked to teach icon painting in Helsinki during the 1960s, but declined. They saw themselves as beginners and felt unqualified to teach either the tempera technique or iconography. In fact, Ina Colliander later attended icon painting classes as a pupil in order to learn the traditional tempera technique (Flinckenberg-Gluschkoff 2002,291). This is surprising as Colliander had already begun to copy and restore icons in Pechory in the 1930s. However, we know from her letters that icons struck her as spiritual and modernist artworks:

I don't appreciate only form in art, as form must have a certain connection with content. Then a balanced work of art can come into existence. It is important to find the correct ratio between form and content. Naturally, both form and content must arise from one's innermost being, but it may be that content proves more important than form. The most naïve form can often reach to unforeseen depths.

(Colliander, quoted in Konttinen 2017, 213) ${ }^{3}$ 


\section{Can women paint icons?}

A youth group for students of Russian origin formed in the Orthodox Parish of Helsinki in 1962, and its members began to take an interest in Russian art and culture with the aim of reviving some of the customs and religious traditions of their forebears. Four of them, Irina Tchernych, Lisa Hoviheimo, Lana Rubanin, and Marianna Flinckenberg, set up an icon painting group the following year. Its leader was Kirill Gluschkoff, who had many international connections, especially among Russian émigrés. Their interest grew from religious and artistic aspirations, which were supported by the arrival of new, imported icons for the Helsinki Orthodox cemetery church. These had been painted by Georgi Morozov and Elena L'vova, Russian émigrés and members of the Ikona association in Paris (Flinckenberg-Gluschkoff 2002, 290-291). In her memoirs, Marianna Flinckenberg-Gluschkoff $(2017,61-62)$ describes the impact of the icons:

We were thrilled. Could we also paint icons like those in the Church of the Prophet Elijah? They were like medieval icon art, colorful and highly stylized compositions, which were completely different from the romantic icons in other parish churches. The icons painted by the Ikona association proved that it was possible even in our day to take icon art "back to its sources" and create holy images, which reflected spiritual asceticism and harmony rather than external beauty.

In 1964, the members of the group received written instructions for icon painting from Reverend Georgi Drobot (1925-2011), who was also a member of the Parisian Icon Association and with whom Kirill Gluschkoff had become acquainted the previous summer. Gluschkoff also connected the group with the icon painter Léonid Ouspensky (1902-1987). In the following years, group members traveled to Paris to learn icon painting technique from Ouspensky, then returned to share their knowledge with others as teachers (Flinckenberg-Gluschkoff 2017, 63-64). By the late 1960s and early 1970 s, this pursuit of traditional iconography had also spread to other parts of Finland. ${ }^{4}$

I have not found any articles or archival documents questioning the authority of either Neiglick-Platonoff or Colliander as iconographers. On the contrary, the two women were generally highly appreciated among Orthodox clergy and parishioners. It is therefore somewhat surprising that the younger newcomers faced resentment in Finnish Orthodox circles. Marianna Flinckenberg-Gluschkoff recollects that especially the members of the Helsinki parish administration and some elderly priests disapproved of their activities. In the critics' opinion, women, particularly young women, did not have the right to paint icons, because they lacked the seriousness of character required for this sacred task. Furthermore, the leader 


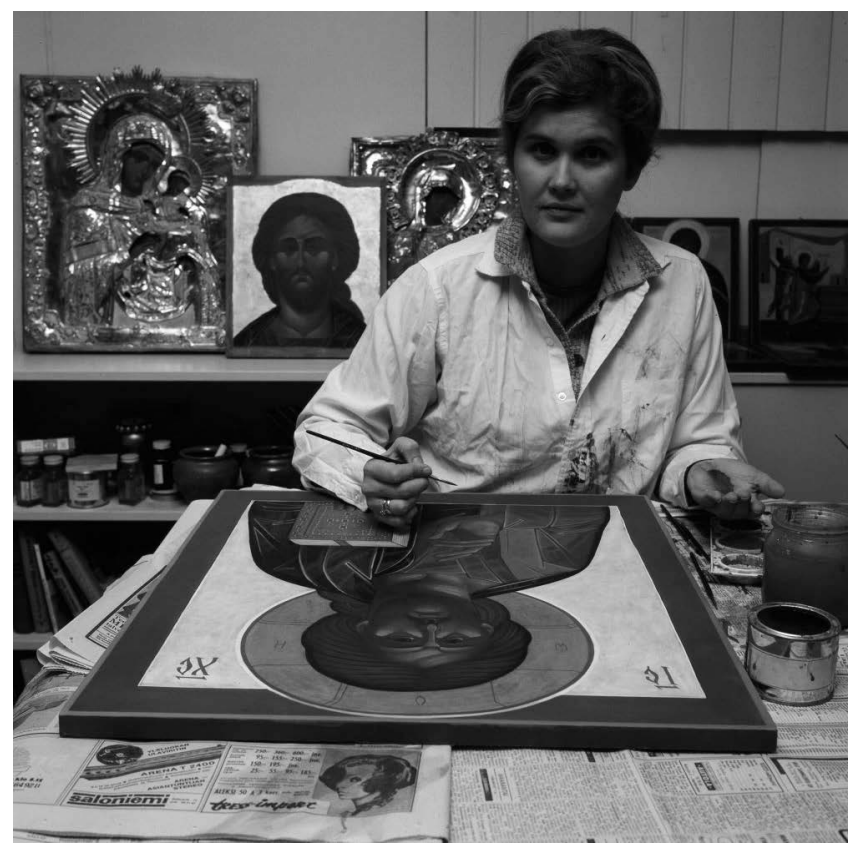

Figure 4.3 Marianna Flinckenberg-Gluschkoff painting an icon of Christ the Almighty at her home in 1968-1969. Following Ouspensky's teaching, she mixed the colors in the palm of her hand. Volker von Bonin / Finnish Heritage Agency (HK7137:1108).

of the Finnish Orthodox Church, Archbishop Paul (1914-1988), had serious reservations regarding the efforts of the Helsinki icon painting group (Flinckenberg-Gluchkoff 2017, 65-66).

The roles of men and women are quite clearly defined in the hierarchy of the Orthodox Church. Women do not have access to priesthood. In Finland, women regularly sang in church choirs, but could not conduct the choir in services until the 1970s, when this position was no longer regarded as a clerical one. An icon painter, however, has no official status in the ecclesiastical hierarchy, although according to tradition icon painters should ideally be monks or at least pious laymen. Strict qualifications for iconographers are set out in the Stoglav $v^{5}$ decisions, together with directives on how a master should teach his apprentices and how bishops should supervise painters and iconography in general. It is understood in these texts that an iconographer should be male (Jääskinen 1984, 90-92). Archbishop Paul's background partly explains his hesitation: he had adopted the teachings and traditions of Russian Orthodoxy in his childhood and youth, at the latest during his years as a monk at the Monastery of Valaam. 
In 1965, Marianna Flinckenberg traveled to Kuopio to teach icon painting, and on the same journey, she met with the Archbishop. Well aware of the Archbishop's critical opinion, she was apprehensive about the discussion. She was careful to explain that the group members were not trying to act as learned iconographers but rather as humble collectors of knowledge and skills. Their sincere goal was to "light the torch" and pass it on to following generations. After a long, profound discussion, Archbishop Paul gave his blessing for their endeavors (Flinckenberg-Gluschkoff 2017, 65-66).

\section{A female art historian challenges tradition}

Revivalist icon painting was the offspring of both the academic and religious discovery of icons. Art-historical research into icons and the Orthodox cultural heritage took major leaps forward in prerevolutionary Russia and like revivalist icon painting it spread to Western Europe with Russian émigrés after the Revolution. In Finland, the art historian Aune Jääskinen (1932-2015), herself Orthodox, was fascinated by the works of Alexander I. Anisimov, Nikodim P. Kondakov, Nikolay P. Likhachev, and others. Inspired by the writings and methods of her Russian predecessors, she wanted to submit the icon "The Mother of God of Konevets" (Konevitsan Jumalanäiti in Finnish) to technical analysis. She proposed that this icon, by then located at the Monastery of New Valaam in Heinävesi, should be examined by experienced restorers to shed light on its actual origin and age.

The Konevets icon is the most cherished holy image in the possession of the Finnish Orthodox Church. Therefore, it is perhaps no wonder that

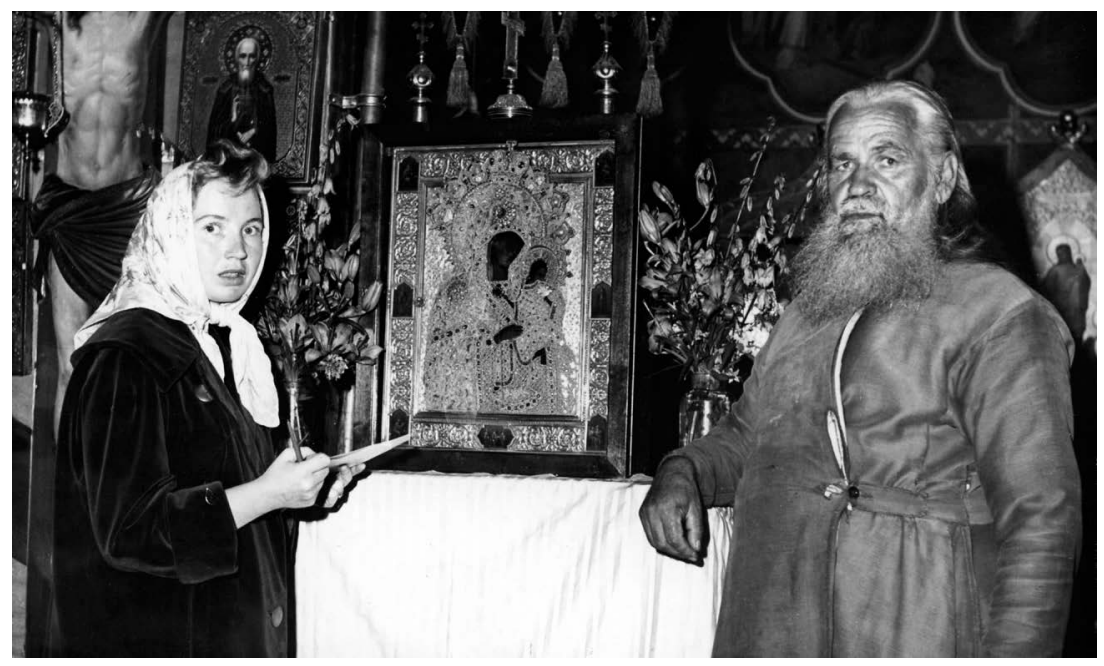

Figure 4.4 The art historian Aune Jääskinen and Hierodeacon Joona in front of the icon "The Mother of God of Konevets." The icon was covered by an enigmatic riza prior to the research that led to its restoration in the 1960s. Private collection. 
Jääskinen's project was vigorously opposed by the leaders of the church for devotional reasons. Jääskinen was ready to challenge the medieval legends, according to which St. Arsenius of Konevets, one of the most prominent of Karelian Saints, had brought the icon from Mount Athos to the island of Konevets in 1393. Jääskinen's research plans led to a long bureaucratic controversy between herself, the Orthodox Church administration, and the Monastery of New Valaam. In 1966, Aune Jääskinen's brother, Reverend Erkki Piiroinen, finally decided to write to Archbishop Paul about her hardships. He assured the Archbishop that his sister was motivated by a sincere desire to help the church by means of academic research. He recounted how his sister had asked him, "is academic research unholy or despicable?" and "is positive affection for an icon and its history un-Orthodox?," noting that he had had no answers to give her. In the letter, he wondered whether the real reason for the researcher's difficulties was that she was a woman. ${ }^{6}$ While he may well have been correct in assuming that the church, as a patriarchal institution, could not accept a female researcher, in this case the researcher's maverick and assertive approach may have proven even more troubling than her gender.

Eventually, the church administration gave in. The icon was taken to Moscow, where it underwent various tests, which shifted its estimated age by approximately 100 years. According to Soviet experts, the icon dated from the late fifteenth or more probably the sixteenth century, and not the fourteenth, as had previously been assumed (Jääskinen 1971, 17). Jääskinen successfully defended her doctoral dissertation on this topic in 1971 and continued to work uncompromisingly as an icon expert. Nevertheless, this episode-alongside similar difficulties she faced in other vocational circles-marked her for life. Her narratives about her professional life mirror those of many male historians in that she portrayed her research career as a heroic struggle through hardships and anguish culminating in conquest and the possession of power over history (Jääskinen 1971, 1998, passim; Smith 2000, 116-129; Husso 2011, 204-207).

The rise of this new type of icon research among Finnish art historians coincided with the arrival of modernist icon painting in Finland. These were two parallel events, undoubtedly interrelated on many levels. Jääskinen's research, lecturing, and publishing activities provided a lot of practical information for revivalist iconographers and future researchers (Merras 2014, 106-107; see also Kahla 2014, 46). Her book about the masterpieces of icon art (Jääskinen 1966) was the first publication on icons with color illustrations to be produced in the Finnish language (Flinckenberg-Gluschkoff 2002, 292).

\section{The post-war cultural policy of the Finnish Orthodox Church}

I have spoken of the Finnish Orthodox Church as if the meaning of the term was quite self-evident. This is not the case. The Finnish-speaking national Orthodox Church was constructed in the 1910s and the 1920s, alongside 


\section{Katariina Husso}

the birth of the Finnish nation state. It involved breaking the jurisdictional tie between the Finnish diocese and the oppressed Orthodox Church in Bolshevik Russia, founding an autonomous Finnish Orthodox archbishopric and replacing Archbishop Seraphim, a Russian, with Herman Aav, who was Estonian. In the same period, Finnish replaced Church Slavonic as the language used in church services in most parts of the country. Icons and church textiles were designed in a more nationalistic fashion.

In the eyes of many Lutheran Finns, the Orthodox minority was associated with Russians and their liturgical use of icons seemed odd, even idolatrous. Many Orthodox Finns changed their Russian names to Finnish ones, including the future Archbishop Paul himself. Many abandoned Orthodoxy and joined the Evangelical Lutheran Church and Orthodox parents frequently allowed their children to be baptized Lutheran. Russian elements in the Finnish Orthodox Church were felt to be burdensome, a negative heritage (Suominen-Kokkonen 2016, passim). This tendency was reflected in cultural matters. From the 1920s, church leaders wanted to phase out Russian influences by controlling church art: architecture, liturgical textiles, church music, and icons.

The nationalist project continued after the Second World War, merging with the more general process through which the Orthodox Church was assimilated into non-Orthodox, secularizing Finnish society. In post-war Finland, ecclesial authorities paid a lot of attention to its public image and cultural identity. The cultural policy of the church was based on a revivalist vision of returning to the original sources of Orthodoxy in the Byzantine tradition (e.g., Loima 2004, 164-170, 190-194; Husso 2011, 198; Takala-Roszczenko 2015, 303-311). The public image of the church was carefully constructed in the media, with many publications introducing the Orthodox artistic heritage and culture to the general public. In particular, the founding of the Orthodox Church Museum in 1957 gained a lot of attention in the press, where its collections were described by Archbishop Paul and the curator of the museum, Protodeacon Leo Kasanko.

As acknowledged artists, Martha Neiglick-Platonoff and Ina Colliander were welcomed into the Finnish Orthodox Church with joy, probably because their status and commitment to Orthodoxy were seen as endorsing the church and strengthening its effort to construct a sophisticated and respectable public face. By this time, both Neiglick-Platonoff and Colliander had also adjusted to the disdained position of female artists in early twentieth-century Finnish society. Female artists constantly negotiated between their creative will and prevailing social circumstances, which constrained their professional and personal lives. Art historian Riitta Konttinen $(2017,6-7,274-287)$ has noted that until recently, female artists were excluded from the official history of art in Finland. The patriarchal order of the Orthodox Church was thus nothing new to Neiglick-Platonoff and Colliander. They felt no need to challenge it. 
Until the arrival of revivalist icon painting directly from Parisian émigré circles, the spokespersons for Orthodox religion and culture in Finland had been bishops and priests. Suddenly, the Helsinki youth group was attracting media attention and appearing frequently in Finnish newspapers, on the radio, and even on television. To further complicate the matter, most of the members were of Russian origin, an attribute that was politically problematic in Finland, both in society and the Orthodox Church.

From this perspective, these artists' gender seems secondary. As far as I can see, the issue at stake was the use of power. Who had the right to represent the national Orthodox Church? Were the representatives obedient to their (male) leaders or did they endanger the carefully constructed public image? The hampering of Aune Jääskinen's research can also be understood in this context. She was independent and persistent and by no means content to repeat what churchmen dictated. She challenged the Orthodox tradition on many levels: first by valuing the scientific facts of her day over the religious convictions of the faithful, and second by adopting the (male) role of an academic historian in contrast to that of an obedient believer.

In the 1970s, icon painting became a very popular hobby in Finland and begun to be taught in various secular adult education institutes around the country. This naturally had many consequences. Due to a shortage of competent teachers, the teaching quality varied a lot. The teachers' lack of in-depth knowledge of Orthodox iconography and theology resulted in iconographical errors and amateurish modes of expression in newly painted icons. Within the Orthodox Church, these images were looked on as libelous and trivialized, leading Archbishop Paul to order priests to bless only icons that were traditional in character (Merras 2014, 107, 110-116). This criticism no longer focused on the gender of the painter but his or her religious knowledge and devotion. Many people outside the church had become attracted to Orthodox icons. Mostly, these were Lutheran Finns with no theological knowledge of Orthodoxy and its canonical definition of sacred images, which apparently caused anxiety among Orthodox clergy and parishioners and spurred them to protect the tradition. ${ }^{7}$

Often, the most vocal "defenders" of icons were women. One was a 21-year-old student, Auli Pietarinen (later Martiskainen). Her article in the Orthodox journal Aamun Koitto (1976, 184-185) emphasized the duty of iconographers: "as an iconographer I am passing on the Holy Tradition. Therefore the responsibility is extensive." She felt that icon painters had a twofold responsibility: first, to tradition and, second, to the public who had the right to experience the tradition in "unchanged and dogmatically correct" form. Icon painters needed to be loyal to the teachings and faith of the Orthodox Church. This required an active relationship with the church: without the holy sacraments, an icon remains without spirit, even though it may be technically perfect. Many Orthodox believers shared these opinions, but did not dare utter them openly. One such person may have been Archbishop Paul himself, for (as Auli Martiskainen mentioned in a personal 
e-mail to the author of this chapter), he had asked her to present her views in a conference for iconographers.

In the 1970s, Archbishop Paul was once more faced with the question of who had the right to paint icons. In an interview for Finland's largest newspaper, Helsingin Sanomat (Väinämö 1976), his answer was imbued with political correctness: "In the Archbishop's opinion, people other than Orthodox believers can paint icons, if they meet certain requisites." Converting to Orthodoxy was not a precondition. Nevertheless, in the very same article, Silja Sandqvist, a teacher of icon painting, expressed a much stricter opinion, mentioning that in Helsinki they had decided to exclude new non-Orthodox members from icon painting courses. Furthermore, according to Sandqvist, icon painting had to be supervised by Orthodox bishops: "An icon is an acknowledgment of the Orthodox faith, and if one cannot understand this faith, it is better to abstain from painting icons." As mentioned, in the 1960s, it was not always clear whether Orthodox women could paint icons or talk about icon painting in public. These examples show that the situation was reversed in the following decade. Female icon painters were making the sharpest comments and the churchmen followed suit in a more reserved manner.

The dispute eventually led to action. In 1977, a special Icon Board was founded to "promote the traditional Orthodox meaning of icon painting and supervise the teaching given about icons." Led by Archbishop Paul and Metropolitan John, its members were noted icon painters, women, who had studied under the guidance of Léonid Ouspensky in Paris. ${ }^{8}$ The Icon Board was to guide painters in theological and iconographical issues. Newly painted icons were brought to inspection events where board members evaluated them. If the board approved it, the icon gained permission to be blessed. If they found errors, the painter received instructions in how to correct his or her painting. Despite its high-minded aim to educate painters and control the production of Orthodox icons, the board's judgments were often perceived as harsh and the inspections aroused resistance. Furthermore, the clergy was somewhat confused as to which icons they were allowed to bless. So this attempt to supervise and direct icon production was not successful, and after a few years, the project was discontinued.

\section{Observations on the present situation}

Icon painting in Finland today has strong roots in Russian émigré revivalism and Western modernism. The number of female iconographers has grown steadily since the 1950 s, although only a few of them have practiced icon painting professionally. Icon painting does not usually provide an adequate livelihood, but is more of a serious task for someone of religious conviction. Margit Lintu, for instance, has steadfastly painted hundreds of icons for various churches alongside being the wife of a parish priest and the mother of five children (Okulov 2007, 15-16). On some occasions, 
artistic education and profession have served as a basis for icon painting. The graphic artist Tuula Murtola was the first teacher of icon painting at Valamo Lay Academy in the 1980s and 1990s, and has also painted many icons for both churches and private use. Liisa Kuningas and Ulla Vaajakallio are other artists who are also icon painters.

Nowadays, women iconographers are a common phenomenon in many countries. One could very well argue that most icon painters in Finland today are women. Many, although not all, belong to the Association of Finnish Icon Painters; 90 percent of its members are women.

Is this female predominance reflected in recent Finnish Orthodox iconography? Orthodox iconography is generally a conventional and established entity with little room for innovation. A traditional approach is usually highly valued and perceived as being canonically correct. Nevertheless, one specific feature of icons produced today can be connected to the painters' gender: the increasing popularity of icons depicting holy women. Alongside the countless variants on the theme of the Mother of God, more and more images of women saints are in churches and private collections. This is probably partly because students of icon painting usually create an icon of their own personal heavenly intercessor. As the number of female painters has increased, so has the number of new icons depicting female saints.

Another recent change concerns style. The revivalists emphasized simplicity. Excessive decorations such as rizas, frames, and gilded accessories were forbidden, since in the eyes of modernist iconographers they spoiled the spiritual and artistic expression. Nowadays, icon painters tend to pursue new means of decorating their icons, and rare iconographic models from the nineteenth and twentieth centuries are back in fashion. This tendency was clearly visible in the icon exhibition arranged by the Association of Finnish Icon Painters at the New Valaam Monastery in 2017-2018. Overall, present-day icons are considerably more eclectic than those produced by the modernists (Husso 2017, 15).

\section{Conclusion}

In Finland, discussions surrounding the gender of icon painters have intertwined with the post-Second World War reconstruction of the identity of the Finnish Orthodox Church as a national minority. Naturally, the active and more independent role of women as artists and professionals has also reflected the changing status of women in Western societies more generally.

When Orthodox Finns were introduced to modern, revivalist trends during the reconstruction period, the new role of women as iconographers highlighted the heretofore unchallenged division between official and unofficial Orthodoxy. Official Orthodoxy was patriarchal and hierarchical; only male specialists were entitled to preach from the solea (the platform in front of the iconostasis) and to represent the Orthodox Church and tradition in the media. In everyday life, women occupied the unofficial sector. 
They were parishioners, priests' wives, and teachers. In these roles, they certainly mediated tradition but in a private capacity and inside the institution of the church.

This situation began to change during the 1950s, when Martha NeiglickPlatonoff and Ina Colliander dominated Orthodox icon art. They paved the way for the next generation of female iconographers and academics who openly challenged the gender division by performing publicly as advocates and interpreters of Orthodox art and culture. The 1960s thus witnessed not just the appearance of revivalist icon art in Finland, but also the entry of women professionals into the fields of icon production and related research. This caused controversy among Orthodox (male) authorities who, since the 1940s, had been carefully constructing a socially acceptable public image for the church based on its artistic heritage and culture.

Finnish revivalist icon painting was strongly influenced by the teachings of the Parisian icon painter Léonid Ouspensky. His theological thinking and interpretations of tradition became well known among Orthodox clergy and iconographers, and he was generally considered to represent the true and canonical teachings of the church. Following Ouspensky, the theological content of icons was seen as their most essential aspect. When icon painting became a popular hobby outside church circles, many Orthodox iconographers felt a need to protect the Orthodox icon tradition from (allegedly) false interpretations and secularization. Women iconographers became the primary guardians of Orthodoxy. They defended theological convictions in public more firmly than their bishops or priests. Perhaps their unofficial position outside the hierarchy and their role as artists allowed them to express their opinions more freely than any official representative of the church could.

Throughout most of the twentieth century, the revivalist discourse was considered to be the true teaching of the church. It was seen as a return to tradition, to original sources. It involved rejecting the artistic expression of (especially) the eighteenth and nineteenth centuries, which was condemned as distorted by Western influences. Paradoxically, what most Orthodox believers see as the church's traditional "theology of the icon," dating back to Byzantine times, is essentially Western European modern art theory, as Evan Freeman $(2018,150)$ has recently pointed out.

From the origins of modernist icon painting, a significant proportion of iconographers have been women, not just in Finland but around the Orthodox world. Icon painting has clearly given women a meaningful way of expressing their artistic creativity in an Orthodox context. There is no direct rule or canon forbidding women from painting holy images. Consequently, the question "can women paint icons?" is more connected to social circumstances than any theological framework. In revivalist thinking, however, the personal attributes of an icon painter are assimilated to his or her artistic work and the very icon itself. An icon depicts church teaching. This makes its creator equal to priests and bishops, who traditionally possess the authority to teach, preach, and guard the dogmas of faith. Pavel Florensky 
$(1996,90)$, whose thinking was strongly influenced by symbolist art theories, even maintained that an iconographer must be much more than a cleric: the role requires greater humility, purity and piety, and a profounder practice of fasting and prayer. Icon painters always discipline themselves more strictly than they are required to, becoming genuine ascetics. If icon painting is indeed seen as equal to priesthood with severe spiritual conviction, women iconographers unavoidably raise the more complex question of women's priesthood in the Orthodox Church.

\section{Notes}

1 It should be made clear that the Orthodox Church does not have a separate "icon theology." Orthodox views about the theological significance and devotional use of icons are generally based on the teachings of St. John of Damascus and the decisions of the ecumenical synods. Furthermore, from the Church's point of view, icons have always been in liturgical use and therefore concepts like "discovery" and "revival" denote rather a specific cultural phenomenon than change in ecclesiastical liturgical practice. (See also Musin 2005, 18; Freeman 2015, 2018, passim.)

2 For instance, Japan's first icon painter Yamashita Rin (1857-1939) studied at the Novodevichiy Convent of the Resurrection in St. Petersburg (Uspensky 1995, 41).

3 All translations from Finnish are by the author.

4 In addition, the Finnish icon painter and conservator Helena Nikkanen passed Ouspensky's teachings on to the United States. She taught icon painting at the Saint Vladimir's Seminary in New York in 1982.

5 The Book of One Hundred Chapters, known as the Stoglav, contains the decisions of the Russian Church Council of 1551.

6 Erkki Piiroinen's letter to Archbishop Paavali, May 8, 1966, in the personal archive of Erkki Piiroinen [Finnish National Archives, Joensuu], XIII E:1. EPA/ $\mathrm{KA} / \mathrm{JO}$.

7 The Uniate priest Robert de Caluwé (1913-2005) was a pioneer revivalist icon painter in Finland. He organized icon painting courses at the ecumenical center in Espoo over the course of several decades, influencing the work of many icon painters. However, his being a priest of the Eastern-Rite Catholic Church caused distrust in Finnish Orthodox circles and his contribution to icon painting was often ignored. Without a doubt, the criticism was partly directed at his activities, but he gradually became more appreciated. In 1977, he received the Pro Finlandia medal in acknowledgment of his artistic work (Elomaa 2010; Husso 2011, 98-99).

8 The artist Petros Sasaki (1939-1999) was invited onto the board, but resigned after the first meeting. The members were Margit Lintu, Auli Pietarinen, Irina Tsernych-Pått, Mervi Siilto, and Silja Sandqvist. (File titled "Ikonineuvosto 1977 " in the personal archive of Archbishop John [Archives of the Finnish Orthodox Church, Kuopio], see esp. minutes and the first bulletin of the Icon Board and Petros Sasaki's letter to Archbishop Paul dated November 17, 1977.)

\section{Bibliography}

Anttonen, Erkki. 2000. “Colliander, Ina.” In Kansallisbiografia-verkkojulkaisu. Studia Biographica 4. Helsinki: Suomalaisen Kirjallisuuden Seura. URN:NBN: fi-fe20051410. 
Belting, Hans. 1996. Likeness and Presence: A History of the Image before the Era of Art. Translated by Edmund Jephcott. Chicago: The University of Chicago Press.

Drucker, Johanna. 1998. "Modernism: An Overview." In Encyclopedia of Aesthetics, Volume 3, edited by Michael Kelly. New York: Oxford University Press.

Elomaa, Jouni. 2010. "Caluwé, Robert de (1913-2005).” In Kansallisbiografiaverkkojulkaisu. Studia Biographica 4. Helsinki: Suomalaisen Kirjallisuuden Seura. URN:NBN:fi-fe20051410.

Flinckenberg-Gluschkoff, Marianna. 2017. Ilkikurinen kompassi: Suunnistusta monen kulttuurin poluilla. Heinävesi: Valamon luostari.

Flinckenberg-Gluschkoff, Marianna. 2002. "Takaisin alkulähteille-ikonimaalaus 1963-1983.” In Ortodoksisuutta eilen ja tänään, edited by Petri Piiroinen, 290-310. Helsinki: Helsingin ortodoksinen seurakunta.

Florensky, Pavel. 1996. Iconostasis. Translated by Donald Sheenan and Olga Andrejev. Crestwood, NY: St Vladimir's Seminary Press.

Freeman, Evan. 2018. "Flesh and Spirit: Divergent Orthodox Readings of the Iconic Body in Byzantium and the Twentieth Century." In Personhood in Byzantine Christian Tradition: Early, Medieval, and Modern Perspectives, edited by Alexis Torrance and Symeon Paschalidis, 137-160. London: Routledge.

Freeman, Evan. 2015. "Rethinking the Role of Style in Orthodox Iconography: The Invention of Tradition in the Writings of Florensky, Ouspensky and Kontoglou." In Church Music and Icons: Windows to Heaven, Proceedings of the Fifth International Conference on Orthodox Church Music, edited by Ivan Moody and Maria Takala-Roszczenko, 350-369. Joensuu: The International Society for Orthodox Church Music.

Husso, Katariina. 2017. "Perinteiden puun versoja." Ikonimaalari 2: 9-15.

Husso, Katariina. 2011. Ikkunoita ikonien ja kirkkoesineiden historian: Suomen autonomisen ortodoksisen kirkon esineellinen kultuuriperintö 1920-1980luvuilla. [Windows on the History of Icons and Ecclesiastical Objects: The Cultural Heritage of Artefacts of the Finnish Autonomous Orthodox Church from the 1920s to the 1980s.] Suomen Muinaismuistoyhdistyksen Aikakauskirja 119. Helsinki: Suomen Muinaismuistoyhdistys.

Hätönen, Helena. 2017. "New Donation of Helene Schjerfbeck Letters to the Finnish National Gallery.” Finnish National Gallery Research 4. https://research. fng.fi/2017/07/25/new-donation-of-helene-schjerfbeck-letters-to-the-finnishnational-gallery/.

Ihanus, Juhani. 2006. "Neiglick, Hjalmar.” Kansallisbiografia-verkkojulkaisu. Studia Biographica 4. Helsinki: Suomalaisen Kirjallisuuden Seura. URN:NBN:fife20051410.

Jääskinen, Aune. 1998. Ikonitohtori. [Icon Doctor.] Helsinki: Otava.

Jääskinen, Aune. 1984. Ikonimaalari uskon ja mystiikan tulkki. [The Icon Painter as an Interpreter of Faith and Mysticism.] Porvoo: WSOY.

Jääskinen, Aune. 1971. The Icon of the Virgin of Konevitsa: A Study of the "Dove Icon" and Its Iconographical Background. Suomen kirkkohistoriallisen seuran toimituksia 85. Helsinki: Suomen kirkkohistoriallinen seura.

Jääskinen, Aune. 1966. Ikonitaiteen Mestariteoksia. Helsinki: Valistus.

Kahla, Elina. 2014. "The New Female Saints of Russia." In Northern Byzantine Icons, edited by Päivi Salmesvuori and Anja Törmä, 45-66. Helsinki: The Finnish National Committee for Byzantine Studies. 
Konttinen, Riitta. 2017. Täältä tullaan! Naistaiteilijat modernin murroksessa. [Here we come! Women Artists in Early Modernism.] Helsinki: Siltala.

Kotkavaara, Kari. 1999. Progeny of the Icon: Émigré Russian Revivalism and the Vicissitudes of the Eastern Orthodox Sacred Image. Åbo: Åbo Akademi University Press.

Lepine, Ayla, Matt Lodder, and Rosalind McKever, eds. 2015. Revival: Memories, Identities, Utopias. London: The Courtauld Institute of Art. http://courtauld. ac.uk/research/courtauld-books-online/revival-memories-identities-utopias.

Loima, Jyrki. 2004. "Nationalism and the Orthodox Church in Finland 18951958." In Nationalism and Orthodoxy: Two Thematic Studies on National Ideologies and their Interaction with the Church, by Teuvo Laitila and Jyrki Loima, 94-203. Helsinki: Renvall Institute Publications.

Merras, Merja. 2014. "Icon Painting in Finland Today." In Northern Byzantine Icons, edited by Päivi Salmesvuori and Anja Törmä, 105-116. Helsinki: The Finnish National Committee for Byzantine Studies.

Moody, Ivan. 2014. Modernism and Orthodox Spirituality in Contemporary Music. Joensuu: The International Society for Orthodox Church Music and Institute of Musicology of SASA.

Musin, Alexander. 2005. "Theology of the Image and the Evolution of Style: The Dogmatic and Canonical Evaluation of Russian Ecclesiastical Art of the Synodal Period." Iconofile 7: 5-25.

Okulov, Sirpa. 2007. "Isä Risto Lintu 40-vuotisesta pappisurasta: Työnjohtajana ja renkinä.” Aamun Koitto 17: 15-16.

Pietarinen, Auli. 1976. "Nuoren ikonimaalarin ajatuksia: Ikonin pyhyydestä ei voi tinkiä.” Aamun Koitto 15: 184-185.

Pollock, Griselda. 2014. "Women, Art and Art History: Gender and Feminist Analyses." Oxford Bibliographies Online. doi:10.1093/OBO/9780199920105-0034.

Smith, Bonnie G. 2000. The Gender of History: Men, Women, and Historical Practice. Cambridge, MA: Harvard University Press.

Suominen-Kokkonen, Renja. 2016. "Negative Heritage in the Historical Culture of Finnish Art History." Konsthistorisk tidskrift/Journal of Art History online: 1-15. doi:10.1080/00233609.2015.1120777.

Takala-Roszczenko, Maria. 2015. "Imported on a Jet-Plane: The Byzantine 'Revival' in Finnish Orthodox Church Music in the 1950s-1960s." In Church Music and Icons: Windows to Heaven, Proceedings of the Fifth International Conference on Orthodox Church Music, edited by Ivan Moody and Maria TakalaRoszczenko, 303-311. Joensuu: The International Society for Orthodox Church Music.

Turtsova, Nina M. 2010. “Naiset ikonimaalareina Venäjällä.” Translated by Eero Balk. Ikonimaalari 1: 8-19.

Uspensky, Michail V. 1995. "An Orthodox Icon by Yamashita Rin-the Japanese Painter of the Meiji Period." Japan Review 6: 37-50.

Väinämö, Rauni. 1976. "Kuka saa maalata ikoneita.” Helsingin Sanomat, July 4. Yazykova, Irina. 2010. Hidden and Triumphant: The Underground Struggle to Save Russian Iconography. Translated by Paul Grenier. Brewster, MA: Paraclete Press. 